\title{
Is Land-Applying Biosolids to Agricultural Areas "Sustainable"? Part One: Assessing the Potential Chronic, Sublethal and Lethal Ecotoxicity of Biosolids on Folsomia Candida and Lumbricus Terrestris.
}

Karen Joan Puddephatt ( $\sim$ karenp@ryerson.ca )

Ryerson University Faculty of Science https://orcid.org/0000-0002-4673-9690

Lynda Helen McCarthy

Ryerson University Faculty of Science

Bryant Micheal Serre

McGill University

Research Article

Keywords: Biosolids, Toxicity, Springtails, Earthworms, Animals, Land-application

Posted Date: February 24th, 2022

DOI: https://doi.org/10.21203/rs.3.rs-1350257/v1

License: (c) (1) This work is licensed under a Creative Commons Attribution 4.0 International License.

Read Full License 


\section{Abstract}

The ecotoxicity of biosolids has been studied extensively using single-compound toxicity testing and 'spiking' studies; however, little knowledge exists on the ecotoxicity of biosolids as they are land-applied in the Canadian context. The purpose of this study is to elucidate the chronic, sublethal (i.e., behavioural), and lethal impacts of land- applying biosolids on the environmentally-relevant Folsomia candida (springtails) and Lumbricus terrestris (earthworms) and concomitantly ascertain whether the use of biosolids for nutrient amendment is a sustainable practice. This study is part of a larger multicompartment program which includes terrestrial plants and aquatic arthropods. After an extensive review of government protocols and existing research in the literature, the current study attempted to elucidate the true nature of the potential ecotoxicity of land-applying biosolids, within a laboratory context. Protocols were developed or modified (e.g., using Evans' boxes (Evans 1947) for chronic and sublethal testing on L. terrestris). Subsequently, two biosolids were tested on springtails and earthworms using avoidance and reproductive bioassay endpoints, at application rates that are standard (8 tonnes ha-1) and worst-case scenarios (22 tonnes ha- ${ }^{-1}$ ). Results indicated no effect of biosolids at the environmentally-relevant concentration; the worst-case scenario exhibited a positive significantly significant relationship (indicating preference for treatment conditions). We suggest that further assessment of the potential ecotoxicological impact of biosolids employ i) environmentally-relevant organisms, ii) appropriate bioassays including the use of whole-organism endpoints, and iii) multikingdom testing (e.g., Kingdom Plantae, Animalia) to comprehensively elucidate answers. Lastly, in situ (field assays) are strongly encouraged in future studies.

\subsection{Introduction}

\subsection{What are Biosolids?}

Biosolids are a major by-product of primary and secondary treatment of residential and industrial effluent in wastewater treatment plants (WWTPs) (Toronto Water 2004; NEBRA 2008; Sewage Treatment 2010); once produced, biosolids are either sent to disposal (including incineration and landfilling), or are landapplied. An otherwise waste product of a burgeoning global urban population, the potential use of landapplying biosolids to amend agricultural soils, among other uses in land restoration (including mine tailings) (CCME 2013), presents an opportunity for using renewable resources within the transition to sustainable development. Biosolids have been, and are increasingly, land-applied to supplement soils with macronutrients (i.e., N, P, K) and organic matter. Moreover, biosolids provide an inexpensive source of essential fertilizer to farmers, support plant growth, improve crop yield, improve soil structure, and reduce soil erosion (Butt and Nuutinen 1998).

Land-applying human wastes as a means of efficient disposal, as well as the recycling of nutrients, has been used by the United States and Canada for over 50 years (Synagro 2002; O'Connor et al. 2005; Pepper et al. 2006; City of Toronto 2009). However, as a human waste product, biosolids can also contain unwanted contaminants or pathogens from industrial and residential wastes (Reilly 2001; Kinney et al. 
2006; Kinney et al. 2008; Wu et al. 2008; Clark et al. 2010; CCME 2013; Lapen et al. 2018). Indeed, the perceived toxicity from contaminants and heavy metals to ecosystems has raised the concerns of many in the public arena (LeBlanc 2007; Vyhnak 2008; City of Toronto 2009) and over the years, these concerns have outweighed the many known benefits to soil and crop fertility. Public opinion, rather than technical problems, have often driven opposition in land-application programs by most government agencies (USEPA 2000; Imrie 2013; Lucas 2020); thus, the use of biosolids have not seen their full potential. Indeed, if deemed "sustainable", the land-application of biosolids would typify true recycling: where nutrients from the soil, which are incorporated into the biomass of crops and then consumed, could be, without recourse for potential detriment to the natural environment, returned to farmed land. To address the public's uncertainty regarding biosolids, there is a need to determine whether biosolids exhibit detrimental impact on the ecosystem.

\subsection{History of Biosolids Research}

To date, most research on the potential toxicity of the land-application of biosolids has focused on the identification, through chemical analysis, of discrete chemicals or classes of chemicals. There exists a huge database identifying the compounds potentially available in biosolids; there are $86,000+$ chemicals on the United States Toxic Substance Control Act Inventory (USEPA 2021). Additionally, several pathogens of concern including bacteria, viruses, protozoa, and helminths have been identified in WWTPs; thus, impact assessment, rather than compound or pathogen identification, is the only scientifically-sound strategy to determine the sustainability of land-application (see Rogers and Smith 2007 for review). To initially address this conundrum, a comprehensive risk assessment study of emerging substances of concern (i.e. ESOCs) and pathogenic substances in biosolids was initiated (McCarthy and Loyo 2015). Additionally, a comprehensive literature review has elucidated that since the early 2000s, biosolids toxicity tests have continued to investigate individual chemicals through 'spiking' tests. Toxicity testing by spiking biosolids grew from prior concerns regarding toxic sediments (Burton Jr 1991). From earlier studies, spiking experiments in biosolids saw select concentrations of chemicals in a substrate raised to, or more often exceeding, environmentally-relevant levels for the purpose of testing potential toxicity. Testing with spiked contaminants has led to several scientific debates over the decades, with Samoiloff (1989) arguing that testing single chemicals in toxicity experiments is irrelevant, as compounds are not present in isolated concentrations in the natural environment. Not only are parent compounds of concern, but also the biodegradative products from microbial or photolytic breakdown. Additionally, Cairns Jr. and Mount (1990) argued that the use of chemical analysis of single compounds was irrelevant for toxicity testing, as organisms - through no dearth of endpoints - will exhibit responses differently to single compounds compared to the chemical mixtures that are traditionally found in their environments. More recently, Crouau et al. (2002) summarized the shortcomings of discrete chemical toxicity tests in stating that they are i) too expensive to conduct for all potential pollutants, ii) provide no information about bioavailability, and iii), do not account for the significant number of possible antagonistic or synergistic reactions. Additionally, Johnson and Sumpter (2016) quote Schoettger of the USEPA: "the US scientific community does not have the time, research facilities, trained personnel, experimental animals, nor financial resources to provide the additional data needed for comfortable 
predictions of the possible environmental effects of a broad spectrum of chemical contaminants". A priori to these concerns, single-chemical studies have the potential to be problematic in biosolids research. Moreover, the testing of individual compounds serves as a form of confirmation bias as researchers are deciding which chemical to test for potential toxicity. In spiking biosolids, the research question changes from one of investigating the fate and impact of land-applying biosolids to the more costly testing of discrete substances on organisms, using land application solely as an exposure pathway.

Notwithstanding this concern, current studies continue to spike biosolids with higher concentrations of substances to test toxicity to terrestrial organisms. For example, Snyder et al. (2011) examined the effect of triclocarban (TCC) (an antibacterial and antifungal agent in disinfectants and soaps) on Eisenia fetida (syn E. foetida) using spiked biosolids. More recently, Jesmer et al. (2017) spiked biosolids with silver nanoparticles (AgNPs) (an antimicrobial) to test toxicity on Eisenia andrei and Folsomia candida; in addition, Velicogna (2019) tested toxicity on Eisenia andrei and Folsomia candida in spiking biosolids with copper sulfate (CuS) (a fungicide and algaecide) and copper oxide nanoparticles (nCuO) (an antimicrobial agent). While single-compound toxicity testing itself is environmentally-irrelevant, the conclusions in media are often founded on these studies, without scientifically experimenting for toxicity when land-applying biosolids at environmentally-relevant concentrations.

\subsection{Behavioural Endpoints}

Lethality bioassays measure mortality or survivorship; contrastingly, Taylor and Scroggins (2013) define sublethal effects as those which include the wide range of "immobility, avoidance, growth, reproduction or fertilization" responses. While behaviour has been critiqued as an endpoint for its inability to be standardized and for field verification (Little 1990; Peakall 1996; Grue et al. 2002), the responses are considered valuable as they serve as an "integration of an organism's molecular, physiological, nervous, sensorial and muscular systems" to changes in the test environment (Raby 2013). Moreover, behavioural testing is more sensitive than lethality testing, offering insight into toxicological impacts when testing substances at environmentally-representative levels of exposure (Little and Finger 1990; Grue et al. 2002; Hellou 2011; Raby 2013). Current government protocols were developed without the inclusion of behavioural endpoints, as such measurements would require the researcher to have a sufficient knowledge of the organism's behaviour under normal and stressed conditions. Additionally, the protocols are concerned with a perceived subjectivity in interpreting effect. The current study however examined behaviour as a sublethal toxicity endpoint and as distinct from the chronic impacts on growth and reproduction. In order to comprehensively study the ecotoxicological impact of biosolids, sublethal, chronic, and lethal endpoints were deemed necessary.

\subsection{Study Overview}

A review of the existing literature suggests that few studies have yet to clarify the impact of municipal biosolids as they are applied, using environmentally-relevant concentrations, to terrestrial biota (see Kinney et al. 2012; Xue et al. 2015; Coors et al. 2016 for example(s)). Thus, the current study is part of a 
larger research program that attempted to determine ecotoxicological impact, and thus clarify the perceived risks, of land-applying biosolids to agricultural fields. This broader study incorporated a battery of toxicity tests and endpoints and followed the potential impact of biosolids from their initial application within the terrestrial compartment, through surface and subsurface flow (as tile drainage), to the aquatic ecosystem. This current sub-study is reporting on the experiments conducted and the observations made regarding the potential impact on environmentally-relevant organisms, including two terrestrial phyla, Folsomia candida (springtails) and Lumbricus terrestris (earthworms). Subsequent testing within the biosolids test battery included four (4) terrestrial plants (Puddephatt et al. 2022). An additional objective of this study was to examine existing toxicity testing protocols.

\subsection{Background}

\subsection{Biosolid Treatment and Toxicity}

There are varying engineered strategies which aim to remove organic contaminants, heavy metals, and pathogens from sludge; a more comprehensive review of biosolids production and treatments can be found in McCarthy and Loyo (2015). Two differing sources of biosolids were utilized in the current study, but in brief, incoming wastewater was treated by physical, mechanical, chemical, and biological means in two stages (City of Guelph, 2009). Primary treatment, a physical process, removes heavier solids (e.g., tree branches, rocks, and faeces); while secondary treatment, a biological process, oxidizes organic pollutants in effluent (Sewage Treatment 2010). Moreover, the addition of chemicals such as aluminium sulphate $(\mathrm{AI} \otimes(\mathrm{SO} \otimes) \mathbb{Z})$ or calcium hydroxide $\left(\mathrm{Ca}(\mathrm{OH})_{2}\right)$ precipitate or coagulate macronutrients from the secondary wastewater (University of Waterloo nd). The solids (or sludge) in both primary and secondary treatment processes are allowed to settle and subsequently sent to a digester where they are anaerobically broken down to more stable forms with a concomitant production of carbon dioxide $\left(\mathrm{CO}_{2}\right)$, ammonia $\left(\mathrm{NH}_{3}\right)$, and methane $\left(\mathrm{CH}_{4}\right)$. The newly-formed biosolids, with a reduced pathogen and volatile organic compounds (VOCs) load are then either land-applied, incinerated, or disposed of in landfills (City of Guelph 2009; Sewage Treatment 2010). Biosolids production is geographically variable, as different treatment methods are utilized across jurisdictions.

The traditional biosolids manufacturing process involves anaerobic digestion and dewatering. Within anaerobic digestion, anoxic microorganisms break down the organic material present in the original sludge and create a product much less offensive in terms of odour and organic contaminants (Residua 2003; DeBruyn and Hiborn 2007). In both aerobic (oxygen-driven) and anaerobic (oxygen-poor) digestion, the volume of the sludge is reduced (University of Waterloo nd). Furthermore, digestion removes approximately $95 \%$ of pathogens from the source sludge (Toronto Water 2019). As a subsequent stage, dewatering reduces water content and pathogens in the resulting biosolids; as a mechanical process, the addition of chemicals releases water bound to organic matter, which is then removed by centrifugation, pressing, or belts (Sewage Treatment 2010). A biosolid from Kitchener, ON and Guelph, ON were used within the current study; Guelph biosolids underwent an additional process using potassium hydroxide 
$(\mathrm{KOH})$ and high temperatures $\left(65-70^{\circ} \mathrm{C}\right)$ to further clean the end-product and create a purportedly pathogen-free substance (City of Guelph 2009).

\subsection{Terrestrial Organism Bioassays}

\subsubsection{Folsomia candida Overview}

The choice of organisms in all parts of this research reflects a long history of ecotoxicology research; for example, Folsomia candida (springtails) were first used in 1956 to assess the impact of the insecticide DDT (dichlorodiphenyltrichloroethane) (Wiles and Krogh 1998). To date, F. candida is used extensively as a test organism for soil toxicity testing, including testing in the land-application of biosolids (Crouau et al. 2002; Wilke et al. 2008; Jesmer et al. 2017; Oleszczuk et al. 2019). Springtails (collembolans) are microarthropods, constituting some of the most abundant organisms on earth (Hopkin 1997; Wiles and Krogh 1998; Fountain and Hopkin 2005; Scott-Fordsmand and Krogh 2005; Krogh 2008). There are 6000 species worldwide of the Folsomia genus (Hopkin 1997; Houseman 2007), many of which are ubiquitous to the various soil types found in Canada (Hopkin 1997; Environment Canada (EC) 2007b). Thus, the environmental relevance of their inclusion in this study is clear. Folsomia candida is the most commonlyused Collembola for toxicology research (Hopkin 1997) and detailed rigorously in Canadian government protocols (EC 2014). Folsomia candida are found extensively in the soil ecosystem; they dwell in upper soil strata, along earthworm burrows, and live in and around agricultural systems, leaf litter, along the edges of streams, and locations containing a high organic content (Fountain and Hopkin 2005; Aldaya et al. 2006; EC 2007b). Many of these environments are where biosolids are applied. Folsomia candida are primary detritivores and are one of the main biological modes responsible for the creation of soil (Campiche et al. 2007; EC 2007b). They are also prey for many endogeic (in the soil) and epigeic (on top of the soil) invertebrates (Krogh 2008) ensuring their position as keystone terrestrial food web members.

\subsubsection{Folsomia candida Toxicity Endpoints}

Anatomically, springtails have six appendages for movement and a forked structure (furcula) along the underside of their abdomen that supports jumping movements; hence, the moniker of "springtails" (Hopkin 1997; EC 2007e). The rapid jumping movements of $F$. candida are a motile response to threats (Wiles and Krogh 1998; Fountain and Hopkin 2005; Houseman 2007). Moreover, F. candida respire through their thin exoskeleton, which is also permeable to water and hydrophilic chemicals in the soil (Krogh 2008). These anatomical characteristics, alongside their ability, through their dermal tissue, to 'taste' chemicals, allow for the exhibition of avoidance behaviour under stressful conditions (Fountain and Hopkin 2005). Thus, the behavioural endpoints measured with springtails are indicative of stress and other impacts from biosolids.

Springtails reproduce by parthenogenesis, a strategy where females produce clones that mature between 21-24 days (EC 2007a). Folsomia eggs are laid in communal heaps, where the small white spheres (about $80-110 \mu \mathrm{m}$ in diameter) take seven to ten days to hatch at $20^{\circ} \mathrm{C}$. The enumeration of visible egg heaps supports easy measurement of reproductive impairment. Overall, F. candida is a "recommended 
biological test method for [toxicity testing with] soil-dwelling terrestrial invertebrates" (EC 2004). While representative of the terrestrial invertebrate group, springtails are also extensively dispersed in the soil ecosystem (Aldaya et al. 2006). Overall, springtails are a relevant organism based on their location relative to where biosolids are applied, and their ideal attributes for ecotoxicological study (ScottFordsmand and Krogh 2005), including i) sublethal (i.e., behavioural), ii) chronic (e.g., reproduction), and iii) lethal (i.e., survivorship) endpoints.

\subsubsection{Lumbricus terrestris Overview}

The macroinvertebrates Lumbricus terrestris are annelids, commonly referred to as earthworms or nightcrawlers. Lumbricus terrestris were introduced to Canadian soils nearly 400 years ago and are now prolific in the terrestrial landscape, excluding the Yukon and Northwest Territories (EC 2007a; Lowe 2008). L. terrestris improve soil fertility and comprise $60-80 \%$ of soil animal biomass in some locations; moreover, $L$. terrestris are found predominantly in moist soils and fields commonly occupied by wheatcorn-soybean rotations (EC 2007a; Kinney et al. 2008). Like springtails, L. terrestris are quintessential to the terrestrial food web as a significant dietary component for birds, reptiles, fish, and mammals, in addition to cycling nutrients and energy (Yeardley et al. 1996; Banks et al. 2006; Kinney et al. 2008; California Environmental Protection Agency (CalEPA) 2009).

These anecic (deep-soil-dwelling) earthworms cycle nutrients extensively through the vertical soil column, using a cylindrical body with the posterior being dorsoventrally-compressed and acting as an anchor in their burrows (EC 2007a; Fründ et al. 2010; Colorado State University 2011; Ayers 2021). They burrow by ingesting detritus, thereby breaking down organic material into smaller pieces for soil microorganisms to degrade further. Contaminants, including heavy metals and hydrophobic and hydrophilic (soil pore water) organic compounds, are sorbed through passive diffusion across the external integument or by desorption in the gut (Banks et al. 2006). This dual exposures (dermal and dietary) to contaminants must therefore be assessed when comprehensively studying the potential ecotoxicological impact of biosolids. Anatomically, L. terrestris have tubercles (small protrusions) along their body which detect unfavourable environmental conditions, which, with the aid of their setae and a peristaltic wave of the musculature of their body, enable them to move away from dangerous environments (Collier 1937; Stephenson et al. 1998). This behavioural response to stress is useful in the avoidance bioassays utilized in this study. Regardless of their environmental relevance and holistic endpoints, Lumbricus terrestris are seldom employed in biosolids toxicity testing. Instead, the Eisenia genus is more commonly used in ecotoxicological assessment (see Artuso et al. (2011) for example).

\subsubsection{Lumbricus terrestris Toxicity Endpoints}

While government protocols stipulate the use of both Eisenia sp. (redworm) and Lumbricus (EC 2007a), the former are perceived to be more amenable to laboratory-rearing conditions and thus are more commonly utilized in biosolids toxicity testing (Velicogna et al. 2012; Groth et al. 2016; Jesmer et al. 2017; Velicogna 2019). However, the Eisenia genus is found across Canada only within organic-rich matter such as composts, manure piles, and gardens. They are rarely found in agricultural fields where 
biosolids are land-applied as these non-burrowing organisms are i) epigean (rarely found in soil, but rather live on or close to the surface), ii) are not true soil dwellers (Crouau et al. 1999; EC 2007a; CalEPA 2009) and iii), only minimally ingest soil. Thus, due to a lack of their environmental relevance, these organisms were not utilized in this current ecotoxicological study.

Conversely, the environmental relevance of using Lumbricus terrestris is not in question and additionally, they have some characteristics that provide further insight when these organisms are exposed to stressful conditions. These earthworms are deep-soil burrowers with highly motile lifestyles and while the addition of behaviour and movement pattern toxicity studies is unusual as most research focuses on lethality (Raby 2013), these endpoint measurements were used in this study Additionally, during hermaphroditic reproduction, these earthworms mate horizontally on the soil surface during evening hours, where cocoons develop after copulating and disengage from the adult body of $L$. terrestris. An average of five viable cocoons and three progeny per cocoon are observed (Butt and Nuutinen 1998), with maturation of the cocoons taking up to one year. The presence (or lack thereof) of cocoons is a desirable indicator of reproductive impairment. In addition to reproduction, the vertical movement of earthworms (as a behavioural indicator) aids in showing the degree of avoidance from the surface amendment of biosolids; thus, their inclusion in biosolids ecotoxicological studies is important.

Lastly, the modification and subsequent use of Evans' boxes (Evans 1947) supported the coupled examination of burrowing behaviour and reproductive impairment in an environmentally-representative assay. Evans (1947) boxes pre-date existing protocols and were historically used to assess the burrowing behaviour of anecic earthworms. Current long-term protocols for Lumbricus terrestris recommend $500 \mathrm{ml}$ Mason jars for 14-day bioassays (EC 2007a) or the use of two-litre vessels for 28-day experiments (OECD 2004). However, the lack of substrate and inability to exhibit burrowing behaviour within the small vessels made the method environmentally irrelevant. In other L. terrestris studies, Evans' boxes are seen only selectively (Blackmon 2009); however, their ability to simulate burrowing behaviour and reproduction across soil horizons makes them viable for detecting the suite of sublethal, chronic, and lethal effects potentially caused by biosolids land-application. Overall, the toxicity impacts utilizing $L$. terrestris are holistically quantifiable through i) sub-lethal (e.g., behavioural), ii) chronic (e.g., reproduction and growth), and iii) lethal (i.e., survivorship) endpoints.

\subsection{Methods}

\subsection{Overview}

The series of bioassays in this study examined the potential sub-lethal, chronic, and lethal effects of landapplying biosolids on two different phyla: Folsomia candida (springtails) and Lumbricus terrestris (earthworms). The suite of bioassays conducted are outlined in Fig. 1.

Taxonomically-verified Folsomia candida (Willem 1902) and Lumbricus terrestris (Linnaeus 1758) were obtained from Environment Canada and Wards Scientific, respectively. All current and historical 
Environment Canada, ISO, and OECD protocols were investigated for Folsomia candida and Lumbricus terrestris and are supplemented by a review of the foundational literature on toxicity testing using these phyla (Hopkin 1997; Wiles and Krogh 1998; Fountain and Hopkin 2005; Aldaya et al. 2006; Crouau and Moia 2006; Campiche et al. 2007). Prior to conducting bioassays, there were modifications made to protocols and a list of all protocols, and when required, modifications, are presented below (Table 1).

Table 1. Protocols examined within the Folsomia candida and Lumbricus terrestris toxicity tests; modification and rationale(s) are provided, as necessary. 


\section{Existing Protocol Modification(s) Rationale(s)}

Folsomia candida

Culturing - Typically, eggs moved to a Organisms (incl. new vessel

Age

Synchronization, enumeration):

(EC 2007c; EC

2007d; EC 2014)

Sublethal Testing (Behavioural):

Chronic Testing (Reproduction):

(EC 2007b; 2008)

\section{- Parent removed after laying} clutch
- Alternative method of removing parent (OECD 2005) favoured, as to limit disruption to eggs
There is no existing protocol for testing avoidance, method was devised (see Section 3.3.1)

- Removal of $12 \mathrm{hr}$. light-dark cycle Reproduction conducted in darkness.

Reproduction bioassays (28 days): extended to a total of 39 days.
- Light-sensitive

Potential impact by presence of light (Hopkin 1997; Fountain and Hopkin 2005).

Additional 11 days did not allow for additional offspring, only growth of clutch to improve accuracy for enumeration.

$\mathrm{N} / \mathrm{a}$

Lethal Testing:

$\mathrm{N} / \mathrm{a}$

(EC 2014)

Lumbricus terrestris

Culturing

Organisms:

(EC 2007a)
Typically fed oats (i.e. Quaker Oats ${ }^{\mathrm{TM}}$ )

Instead, fed wetted dried leaves from non-urban areas; supplemented by corn meal.
Preliminary tests: oats began to mould quickly. Preferred by Eisenia sp., not Lumbricus (Fründ et al. 2010; Ayers 2021).

Dried leaves (e.g., Acer saccharum) from non-urban area, Southern Ontario

Corn meal: preferred food supplement by worm breeders (pers. comm. Wards Scientific, n.d.).

Kaushik chambers did not accommodate vertical dwelling patterns nor diameter of $L$. terrestris for movement, relative to the perforations in partitions.

(EC 2004; EC 2007a)

Avoidance behaviour commonly tested using Kaushik chambers.

- Instead, rectangular bins containing reference and treatment soil

Earthworms placed along the surface of divided soil; preference recorded after 72 hours.

* The non-urban source was not pesticide-treated and was used to ensure a lack of impact from airborne pollutants in the feeding protocol; however, the potential for long-range transport of contaminants was not disregarded. 


\begin{tabular}{|c|c|c|}
\hline Existing Protocol & Modification(s) & Rationale(s) \\
\hline $\begin{array}{l}\text { Sublethal and } \\
\text { Chronic Testing } \\
\text { (Evans' Boxes } \\
\text { long-term } \\
\text { exposure): } \\
\text { (EC 2007a; OECD } \\
1984, \text { OECD } \\
\text { 2004) }\end{array}$ & $\begin{array}{l}\text { Exposure traditionally } \\
\text { measured in } 500 \mathrm{~mL} \text { glass } \\
\text { vessels } \\
\text { Evans' boxes (Evans 1947) } \\
\text { used instead. } \\
\text { 28-day lethality/ } 48 \text {-day } \\
\text { chronic bioassays (OECD } \\
2004 \text { ) extended to } 30 \text { and } 90 \text { - } \\
\text { day bioassays, respectively }\end{array}$ & $\begin{array}{l}\text { Evans (1947) boxes: more accurate } \\
\text { representation of environmental conditions; } \\
\text { improved examination of burrowing } \\
\text { behaviour } \\
\text { unsuitable for long-term monitoring. } \\
\text { Preliminary testing using } 500 \mathrm{~mL} \text { vels: } \\
\text { lifecycle endpoints }\end{array}$ \\
\hline
\end{tabular}

The following sections outline the materials and methods used to prepare and conduct the bioassays for both organisms.

\subsection{Biosolids Preparation}

Biosolids-amended soil (herein "treatment" soil) represented land-application concentrations at environmentally-relevant levels (8 tonnes ha ${ }^{-1}$ as dry-weight (DW)) and a worse-case application scenario (22 tonnes ha ${ }^{-1} \mathrm{DW}$ ) within a 5-year nutrient management program. Organisms were first exposed to the worst-case application scenario; if observation of significant effect (whether positive or negative) was noted or there appeared to be a need for greater replication, organisms were sequentially exposed to the environmentally-relevant concentration ( 8 tonnes ha- ${ }^{-1}$ ) from Guelph biosolids. Consequently, springtails were exposed to both concentrations and earthworm bioassays were conducted solely using the worst-case (22 tonnes $\mathrm{ha}^{-1}$ ) scenario.

The "reference" soil used was a Perth clay loam, a grey-brown podzolic retrieved from an Ontario Ministry of Agriculture, Food and Rural Affairs (OMAFRA) agricultural research site in Stratford, ON. The soil was designated to be pesticide- and organic-contaminant-free (Michael Payne, pers. comm. OMAFRA (retired), 2013). Reference soils were moistened, relative to the humidity from the biosolids additions, with dechlorinated municipal drinking water (DMDW).

\subsection{Folsomia candida Bioassays}

\subsubsection{Folsomia candida Sub-Lethal Bioassays}

The Folsomia candida sub-lethal (avoidance) experiments were conducted in i) 100-minute, ii) 3-day, iii) 7-day, and iv) 14-day bioassays. The 100-minute avoidance bioassays were conducted in Petri dishes. In each of the ten microcosms, reference and treatment soil-coated filter paper lined opposite sides of the Petri dish, with a $2 \mathrm{~mm}$ gap between filter papers. Each 100-minute bioassay used five springtails placed 
in the middle of the dish between the two substrates; the location of each collembolan (in reference or treatment) was noted in 20-minute increments, until the end of each bioassay.

The i) 3-day, ii) 7-day, and iii) 14-day sub-lethal tests were conducted sequentially in ten Mason jars $(125 \mathrm{~mL})$. These bioassay vessels were prepared using a $1 \mathrm{~cm}$ base of Plaster of Paris (mixture of lime and sand) and activated charcoal (EC 2007e). Each jar received $15 \mathrm{~g}$ of both reference and treatment soil, separated by dividers. Upon subsequent removal of the dividers, ten age-synchronized springtails were set along the middle of the two substrates. The bioassays were placed in dark conditions at $20^{\circ} \pm 2^{\circ} \mathrm{C}$, undisturbed, for the duration of the bioassay. Upon completion of the specified time intervals (e.g., 3-day), dividers were re-inserted, and the location of the springtails noted. After counting, dividers were removed, and the bioassays were returned to dark conditions until the next time period (e.g., 7-day). Folsomia candida were not fed during these sub-lethal bioassays.

\subsubsection{Folsomia candida Chronic Bioassay}

The chronic (i.e., reproductive testing) bioassay measured the number of individuals after 39 days. In the chronic bioassay, 10 Mason jars ( 5 reference, 5 treatment) were prepared with $1 \mathrm{~cm}$ of the Plaster of Paris and activated charcoal substrate with the subsequent addition of $30 \mathrm{~g}$ of reference or treatment soil. Ten age-synchronized, 10-12-days-old springtails were added to either reference or treatment bioassays. Organisms were fed $2 \mathrm{mg}$ of dry yeast (e.g., Fleishmann's $\mathrm{s}^{\mathrm{TM}}$ ) hydrated with 1 drop of dechlorinated water, biweekly per recommendation of Crouau and Cazes (2003) for the 39 days. Reproduction bioassays were conducted in continuous darkness, as opposed to the recommended 12:12 light-dark cycle (Hopkin 1997; EC 2014) (see Table 1). Temperatures were consistent at $20^{\circ} \pm 2^{\circ} \mathrm{C}$. Organisms were enumerated at the end of the 39 days as per government protocols (EC 2014).

\subsection{Lumbricus terrestris Bioassays}

\subsubsection{Lumbricus terrestris Sub-lethal Bioassay}

The sub-lethal (e.g., behavioural) toxicity test of biosolids on Lumbricus terrestris was measured over 72 hours. The avoidance tests for the earthworms were conducted in ten rectangular, $34.2 \mathrm{~cm}$ (long) $x$ $11.8 \mathrm{~cm}$ (wide) $\times 20.9 \mathrm{~cm}$ (deep), plastic bins (herein "Karen's boxes") instead of Kaushik Chambers. A plastic divider ( $34 \mathrm{~cm}$ long) separated reference and treatment soils in the bins tangentially; once removed, earthworms of similar weight were set along the center of both substrates. If the worm had not burrowed within 30 minutes, it was replaced. The initial time and substrate $L$. terrestris entered was recorded; bins were then covered with sterile gauze (to still facilitate air exchange) and left undisturbed for the duration of the bioassay. Bioassays were conducted in darkness to simulate below-ground conditions. Upon completion, dividers were then re-inserted and the location of $L$. terrestris in either substrate was noted. Lethality was recorded, if observed. Vessels were rotated $180^{\circ}$ between trials as part of a randomization procedure.

\subsubsection{Lumbricus terrestris Evans' Box Bioassays}


The long-term bioassay in modified Evans' boxes measured i) chronic (e.g., reproduction via cocoon production), ii) lethal (i.e., survivorship), and sub-lethal (e.g., burrowing behaviour) endpoints. This assay included endpoints of the number and weight of organisms, in addition to the number/presence of cocoons. At the end of the earthworm long-term bioassays, mean survival, as well as pathological symptoms (e.g., erythema, ulceration, lesions, and discolouration), and behavioural responses (e.g., tactile response, locomotion, lethargy, casting, midden productions, and the presence of non-burrowing earthworms) were observed and measured (if present).

Within this current study, ten Evans' boxes ( 5 reference, 5 treatment) were modified to accommodate greater horizontal and vertical movement and included a top bin (herein "reproductive chamber") to simulate, and subsequently promote, reproduction conditions in this long-term bioassay. The Evans' box was $20 \mathrm{~cm}$ (long) x $8 \mathrm{~cm}$ (wide) x $100 \mathrm{~cm}$ (deep) and the reproductive chamber on top was $34.2 \mathrm{~cm} \times$ $11.8 \mathrm{~cm} \times 20.9 \mathrm{~cm}$. Boxes were secured using a $30 \mathrm{~cm} \times 30 \mathrm{~cm}$ base plate (Fig. 2). The Evans' boxes were constructed with one side as an operable door, to allow for opening during test intervals at i) 7 days, ii) 28 days, and iii) 90 days. This is the first known study to use Evans' boxes (Evans 1947) for examining the long-term impacts of land-applied biosolids.

The substrate within all Evans' boxes was assembled in an effort to rudimentarily simulate soil horizons; the bottom $10 \mathrm{~cm}$ used sand (as to avoid compaction) and the rest was filled with reference soil. Subsequent bioassay setups differed in either reference or treatment soil within the top $15 \mathrm{~cm}$ of the combined chamber. Once filled, five adult $L$. terrestris ( $3-10 \mathrm{~g}$ each) were set on top of the reproductive chambers; each chamber had approximately similar combined earthworm biomass. The time taken to burrow into the underlying Evans' boxes was recorded and non-burrowing worms, after 30 minutes, were replaced. Sterile gauze was secured over the reproductive chambers to prevent escape and lab temperatures were kept at $19 \pm 1^{\circ} \mathrm{C}$. The sides of the reproductive chambers were not covered in order to replicate above-ground conditions; however, the Evans' boxes were wrapped in dark fabric to simulate underground conditions. Lumbricus terrestris were fed bi-weekly at the top of the reproductive chamber with dried leaves and cornmeal; during feeding, soil moisture and overall conditions of the chambers were measured. Using a flashlight, the location (e.g., as a behavioural response) and abundance (i.e., lethality) of the earthworms were determined at the test intervals. Removal of the reproductive chamber and subsequent opening of the Evans' box after 90 days (end of the chronic bioassays) allowed for a thorough examination of test endpoints across the soil column (number of living organisms, health, location, weight, burrowing patterns, and the presence/number of cocoons).

\subsection{Statistical Analyses}

Avoidance bioassays of the two genera were assessed using the Chi-squared test, a non-parametric analysis (Key 1997). Avoidance tests and long-term bioassays were analyzed using the Kruskal-Wallis analog of a one-way analysis of variance (ANOVA). A paired t-test analyzed the directionality of $L$. terrestris bioassays in the rectangular vessels. This parametric test compares the means of the same subject either over time (as in before/after situations) or in differing circumstances/treatments (e.g., changes in the orientation of reference soil was located (left or right) in repeated trials) (Zar 1994; 
McDonald 2009). Positive test results are herein represented as "POS", negative results as "NEG", and endpoints with no significant difference reported as "NSD".

\subsection{Results And Discussion}

The initial hypothesis of this study was, on the basis of other findings in the literature, that biosolids would show a potentially deleterious effect on the two terrestrial bioassay organisms when applied at the worst-case application scenario and the environmentally-relevant application scenario. Additionally, the purpose of this study was to determine what those the potential effects would be on the two chosen terrestrial invertebrates, Folsomia candida (springtails) and Lumbricus terrestris (earthworms). Overall, the conclusions of this study indicate that biosolids had little noticeable negative impact when applied at environmentally-relevant concentrations. When effects were observed, they were in the worst-case scenario application (22 tonnes ha- ${ }^{-1}$ ), and were a positive statistically-significant difference, indicating a preference for treatment conditions.

\subsection{Folsomia candida Bioassays}

\subsubsection{Folsomia candida Sub-Lethal Bioassays Results}

The series of Folsomia candida microcosms in this study assessed ecotoxicological impact through sublethal (avoidance), chronic (reproduction), and lethal (e.g., survivorship) endpoints. Overall, the observed impact of biosolids as the bioassay progressed (from 100 minutes to 14days) was nonsignificant. (Table 2). In all other trials, across both application regime and timeframes, no statistically-significant effect was observed.

Table 2. Sub-lethal (Avoidance) Bioassay Results for Folsomia candida in Guelph and Kitchener Biosolids. 


\begin{tabular}{|c|c|c|c|c|c|c|}
\hline \multirow[t]{2}{*}{$\begin{array}{l}\text { Sub-Lethal } \\
\text { Trials }\end{array}$} & \multirow[t]{2}{*}{$\begin{array}{l}\text { Exposure } \\
\text { (time) }\end{array}$} & \multicolumn{2}{|c|}{$\begin{array}{l}\text { Presence in Substrates (\% of } \\
\text { total } \pm S D \text { ) }\end{array}$} & \multirow[t]{2}{*}{$\begin{array}{l}\text { Impact of } \\
\text { Biosolids }\end{array}$} & \multicolumn{2}{|c|}{$\begin{array}{l}\text { Kruskal-Wallis } \\
\text { (ANOVA) Results }\end{array}$} \\
\hline & & Reference & Treatments & & $\begin{array}{l}\mathrm{H}- \\
\text { Statistic }\end{array}$ & Significance \\
\hline \multicolumn{7}{|c|}{8 tonnes/ha - Guelph Biosolids } \\
\hline Trial 1 & 14 days & $38 \pm 22$ & $62 \pm 22$ & NSD & $H=1.9$ & $p=0.17$ \\
\hline \multicolumn{7}{|c|}{22 tonnes/ha - Kitchener Biosolids } \\
\hline Trial 1 & $\begin{array}{l}100 \\
\text { minutes }\end{array}$ & $28 \pm 11$ & $72 \pm 11$ & POS & $H=7.3$ & $p<0.05$ \\
\hline Trial 2 & $\begin{array}{l}100 \\
\text { minutes }\end{array}$ & $36 \pm 17$ & $64 \pm 17$ & POS & $\mathrm{H}=4.2$ & $p<0.05$ \\
\hline Trial 1 & 3 days & $59 \pm 33$ & $41 \pm 33$ & NSD & $\mathrm{H}=0.5$ & $p=0.46$ \\
\hline Trial 1 & 7 days & $52 \pm 17$ & $48 \pm 17$ & NSD & $\mathrm{H}=0.1$ & $p=0.75$ \\
\hline Trial 2 & 7 days & $49 \pm 24$ & $51 \pm 24$ & NSD & $\mathrm{H}=0.5$ & $p=0.46$ \\
\hline Trial 1 & 14 days & $59 \pm 17$ & $41 \pm 17$ & NSD & $H=1.8$ & $p=0.17$ \\
\hline
\end{tabular}

Despite the suggestion of employing sub-lethal testing endpoints (e.g., avoidance behaviour) on springtails using biosolids (see Li et al. 2020 for example), studies in the literature instead tend to focus on lethality and chronic toxicity tests. Testing for sub-lethal effects (behaviour and avoidance) of a specific substrate is more common in studies using annelids (e.g., E. fetida, E. andrei, and less commonly, L. terrestris), rather than in microarthropods such as springtails, as F. candida bioassays predominantly measure lethality (Crouau et al. 2002; Wilke et al. 2008; Jesmer et al. 2017; Oleszczuk et al. 2019). The select studies which test avoidance behaviors (as sublethal) for springtails have done so in the context of applications of pesticides, pharmaceuticals and personal care products (PPCPs), nanomaterials, and industrial compounds (see Gomes et al. 2017 for review), as opposed to biosolids explicitly. The mobility of springtails is a relevant environmental indicator, in spite of its minimal use in past and current studies, as it adds breadth to understanding the ecotoxicological impacts of contaminated soils and sediments. Regardless, toxicity testing using sublethal effects is not common as existing government protocols favour lethality and chronic testing as endpoints (Natal-da-Luz et al. 2008).

\subsubsection{Folsomia candida Chronic Bioassay Results}

In reproduction testing, no statistically-significant difference for substrate preference was noted among the exposure scenarios (Table 3). Likewise, no difference was observed using the autoclaved soil (i.e., sterilized to ensure no indigenous organisms). 
Table 3. Chronic Bioassay Results for Folsomia candida in Guelph and Kitchener Biosolids; NSD = No Significant Difference.

\begin{tabular}{|c|c|c|c|c|c|c|}
\hline \multirow[t]{2}{*}{$\begin{array}{l}\text { Chronic } \\
\text { Trials }\end{array}$} & \multirow[t]{2}{*}{$\begin{array}{l}\text { Exposure } \\
\text { (Time) }\end{array}$} & \multicolumn{2}{|c|}{$\begin{array}{l}\text { Presence in Substrates } \\
\text { (\% of total } \pm \text { SD) }\end{array}$} & \multirow[t]{2}{*}{$\begin{array}{l}\text { Impact of } \\
\text { Biosolids }\end{array}$} & \multicolumn{2}{|c|}{ T-Test Results } \\
\hline & & Reference & Treatment & & $\stackrel{t-}{\text { Statistic }}$ & Significance \\
\hline \multicolumn{7}{|c|}{8 tonnes/ha - Guelph Biosolids } \\
\hline Trial 1 & 39 days & $836 \pm 156$ & $834 \pm 541$ & NSD & $t=0.01$ & $p=0.994$ \\
\hline \multicolumn{7}{|c|}{22 tonnes/ha - Kitchener Biosolids } \\
\hline Trial 1 & 39 days & $\begin{array}{l}1588 \pm \\
503\end{array}$ & $\begin{array}{l}1426 \pm \\
530\end{array}$ & NSD & $t=4.98$ & $p=0.632$ \\
\hline Trial 2 & 39 days & $\begin{array}{l}1894 \pm \\
294\end{array}$ & $282 \pm 175$ & NSD & $t=10.5$ & $p<0.05$ \\
\hline \multirow[t]{2}{*}{$\begin{array}{l}\text { Chronic } \\
\text { Trials }\end{array}$} & \multirow[t]{2}{*}{$\begin{array}{l}\text { Exposure } \\
\text { (Time) }\end{array}$} & \multicolumn{2}{|c|}{$\begin{array}{l}\text { Presence in Substrates } \\
\text { (\% of total } \pm \text { SD) }\end{array}$} & \multirow[t]{2}{*}{$\begin{array}{l}\text { Impact of } \\
\text { Biosolids }\end{array}$} & \multicolumn{2}{|c|}{$\begin{array}{l}\text { Kruskal-Wallis } \\
\text { (ANOVA) Results }\end{array}$} \\
\hline & & & & & $\begin{array}{l}\mathrm{H}- \\
\text { Statistic }\end{array}$ & Significance \\
\hline \multicolumn{7}{|c|}{ Autoclaved Soil } \\
\hline Trial 1 & 39 days & $\begin{array}{l}1698 \pm \\
614\end{array}$ & N/A & NSD & $\mathrm{H}=0.31$ & $p=0.739$ \\
\hline
\end{tabular}

Within the literature, study conclusions from experiments using non-spiked biosolids are variable. Groth et al. (2016) found that reproduction bioassays in biosolids-amended soils produced a minimum of 100 juveniles/vessel higher than numbers observed in reference soils (2016): the difference between population abundance within reference and treatment soils across the trials did meet this criterion to signal an effect, nor were there a statistically significant impact of biosolids observed. Artuso et al. (2011) found that the number of springtails in reproduction tests was significantly lower at higher application rates (20 tonnes $\mathrm{ha}^{-1}$ ), although no significant effects were observed at environmentallyrelevant application rates (2-10 tonnes $\left.\mathrm{ha}^{-1}\right)$. Other studies using spiked biosolids consistently see an effect on reproduction (Staples et al. 2010; Cardoso et al. 2021). They do not, however, reflect the true nature of biosolids as they are produced and applied in agri-ecosystems. To reiterate, there are differing observations in the literature regarding the lack of, or presence of, significant impacts of biosolids landapplication on springtail reproduction.

\subsection{Lumbricus Terrestris Bioassays}




\subsubsection{Lumbricus terrestris Sub-Lethal Bioassay Results}

Lumbricus terrestris avoidance tests were carried out in Karen's boxes and not in the government protocol suggestion of Kaushik chambers. The avoidance trial chi-square test revealed no significant difference in preference for reference or treatment conditions; however, the relative abundance in either side suggests a preference for reference conditions (Table 4). More trial replicates are required to better understand the preference of earthworms in the 3-day avoidance bioassay. To clarify these findings, further trials at both the 8- and 22-tonnes ha $^{-1}$ application regime are necessary to ascertain whether toxicity is attributed to biosolids when applied at environmentally-relevant levels. However, these preliminary results show promise for future tests, using avoidance endpoints in straightforward test vessels, to elucidate whether there is a significant effect of biosolids on $L$. terrestris in either the extreme application scenario, or even the environmentally-relevant concentrations, as would be conferred to soils in the proper land-application of biosolids.

Table 4. Sub-Lethal Bioassay and Directionality Test Results for Lumbricus terrestris in Kitchener Biosolids; NSD = No Significant Difference.

\begin{tabular}{|lcclll|}
\hline $\begin{array}{l}\text { Sub-Lethal } \\
\text { Trials }\end{array}$ & $\begin{array}{l}\text { Exposure } \\
\text { (Time) }\end{array}$ & \multicolumn{2}{l}{$\begin{array}{l}\text { Presence in Substrates } \\
(\% \text { of total } \pm \text { SD })\end{array}$} & $\begin{array}{l}\text { Impact of } \\
\text { Biosolids }\end{array}$ & T-Test Results \\
\hline & Reference & Treatment & & $\begin{array}{l}t \text { - } \\
\text { Statistic }\end{array}$ & Significance \\
\hline 22 tonnes/ha - Kitchener Biosolids & & & & \\
\hline Trial 1 & $9.5 \pm 0.5$ & $9.5 \pm 0.5$ & NSD & $t=0.0$ & $p=1.0$ \\
\hline Trial 2 & $11 \pm 0.5$ & $9 \pm 0.5$ & NSD & $t=0.49$ & $p=0.62$ \\
\hline Trial 3 & $10 \pm 0.5$ & $9 \pm 0.5$ & NSD & $t=0.22$ & $p=0.83$ \\
\hline
\end{tabular}

Other biosolid sub-lethal tests preferentially use the Eisenia genus (fetida or andrei) instead of $L$. terrestris. Melo et al. (2017) found a preference of E. fetida for amended soils at environmentally-relevant application rates of a biosolids hydrochar, with an increasing preference for reference conditions with increasing application rates up to 72.5 tonnes $\mathrm{ha}^{-1}$. Using a series of different engineered biosolids products, Huguier et al. (2015) found significant negative effects of biosolids on earthworms' preference of soil substrates (when applied 10 times above-recommendation for application); however, consistent impact was only noted when biosolids were applied 50 times above recommendations. Near environmentally-relevant application rates, Huguier et al. (2015) find no significant difference in preference between reference and treatment conditions. Bouldin et al. (2016) noted an overwhelming and significant difference in the preference of E. fetida (> 80\%) for treatment conditions within two different biosolid treatments. While Environment Canada avoidance protocols are interchangeably conducted with 
L. terrestris (EC 2007a), the globally referenced ISO 17512-1 framework focuses exclusively on the Eisenia genus (ISO 2008). Moreover, the difference in i) environmental relevance of Eisenia, ii) burrowing behaviour (Crouau et al. 1999), and iii) elevated sensitivity of L. terrestris to environmental stressors (Sanchez-Hernandez 2021), compounded by iv) changing the testing vessel to a rectangular bin limits the comparability of the toxicity test results among the two organisms.

\subsubsection{Lumbricus terrestris Evans' Box Bioassay Results}

Long-term bioassays ( 90 days) were conducted in Evans' boxes as the environmental relevance of longer exposure bioassays was key to assessing comprehensive impact. Toxicity results for Lumbricus terrestris at the 22 tonnes ha ${ }^{-1}$ application regime indicate no significant difference, across all endpoints, for either soil conditions (Table 5). Pathological indicators of anatomical stress were not observed for earthworms in either reference or treatment Evans' boxes (e.g., lethargy, midden production).

Table 5. Evans' Boxes Chronic and Sublethal Bioassay Results for Lumbricus terrestris in Kitchener Biosolids after 90-day exposure; NSD = No Significant Difference. 


\begin{tabular}{|c|c|c|c|c|c|c|}
\hline \multirow[t]{3}{*}{ Endpoints } & \multirow[t]{3}{*}{$\begin{array}{l}\text { Unit of } \\
\text { Measure }\end{array}$} & \multirow{2}{*}{\multicolumn{2}{|c|}{$\begin{array}{l}\text { Responses in } \\
\text { Substrates } \\
\text { (Mean } \pm \text { SD) }\end{array}$}} & \multirow[t]{3}{*}{$\begin{array}{l}\text { Impact of } \\
\text { Biosolids }\end{array}$} & \multirow{2}{*}{\multicolumn{2}{|c|}{ T-Test Results }} \\
\hline & & & & & & \\
\hline & & Reference & Treatment & & $\stackrel{t-}{\text { Statistic }}$ & Significance \\
\hline \multicolumn{7}{|c|}{22 tonnes/ha - Kitchener Biosolids } \\
\hline $\begin{array}{l}\text { Initial weight of } \\
\text { worms }\end{array}$ & g & $\begin{array}{l}101.8 \pm \\
0.9\end{array}$ & $\begin{array}{l}106.6 \pm \\
1.5\end{array}$ & NSD & $t=1.23$ & $p=0.254$ \\
\hline $\begin{array}{l}\text { Weight of worms } \\
\text { / box }\end{array}$ & g & $20.4 \pm 0.9$ & $21.3 \pm 1.5$ & NSD & $t=1.23$ & $p=0.254$ \\
\hline $\begin{array}{l}\text { Weight per worm } \\
\text { (mean) }\end{array}$ & g & $4.1 \pm 0.2$ & $4.3 \pm 0.3$ & NSD & $t=1.24$ & $p=0.250$ \\
\hline $\begin{array}{l}\text { Weight at } \\
\text { termination }(90 \mathrm{~d})\end{array}$ & g & $92.9 \pm 5.5$ & $87.2 \pm 7.3$ & NSD & $t=0.28$ & $p=0.786$ \\
\hline $\begin{array}{l}\text { Weight of worms } \\
\text { / box }(90 \mathrm{~d})\end{array}$ & g & $18.6 \pm 5.5$ & $17.5 \pm 7.3$ & NSD & $t=0.28$ & $p=0.786$ \\
\hline $\begin{array}{l}\text { Weight per worm } \\
\text { (90 d) }\end{array}$ & g & $4.6 \pm 0.7$ & $5.1 \pm 0.3$ & NSD & $t=1.4$ & $p=0.187$ \\
\hline \multirow[t]{2}{*}{ Endpoints } & \multirow[t]{2}{*}{$\begin{array}{l}\text { Unit of } \\
\text { Measure }\end{array}$} & \multicolumn{2}{|c|}{$\begin{array}{l}\text { Presence in Substrates } \\
\text { (Mean } \pm \text { SD) }\end{array}$} & \multirow[t]{2}{*}{$\begin{array}{l}\text { Impact of } \\
\text { Biosolids }\end{array}$} & \multicolumn{2}{|c|}{$\begin{array}{l}\text { Kruskal-Wallis } \\
\text { (ANOVA) Results }\end{array}$} \\
\hline & & & & & $\begin{array}{l}\mathrm{H}- \\
\text { Statistic }\end{array}$ & Significance \\
\hline \multicolumn{7}{|c|}{22 tonnes/ha - Kitchener Biosolids } \\
\hline Number alive (7d) & \# & $24.0 \pm 0.4$ & $24.0 \pm 0.4$ & NSD & $\mathrm{H}=0.00$ & $p=1.000$ \\
\hline $\begin{array}{l}\text { Number alive (28 } \\
\text { d) }\end{array}$ & \# & $23.0 \pm 0.5$ & $24.0 \pm 0.4$ & NSD & $H=0.43$ & $p=0.513$ \\
\hline $\begin{array}{l}\text { Number alive (90 } \\
\text { d) }\end{array}$ & \# & $20.0 \pm 1.0$ & $17.0 \pm 1.3$ & NSD & $H=0.57$ & $p=0.451$ \\
\hline
\end{tabular}

Huguier et al. (2015) found a significant reproduction effect on E. fetida at Day 56 for biosolidamendments equal to or greater than 5 times the recommended applications. Similarly, to the rectangular avoidance vessels, there is minimal literature which has tested for chronic and sublethal toxicity of $L$. terrestris, limiting our ability to further validate this (reword, please). However, longer-term bioassays (e.g., 96 months) in Coors et al. (2016) echo the findings of the current study regarding the lack of significant effect among biosolids and reference conditions. Research on the validity of utilizing Evans' boxes to conduct biosolids toxicity testing exists (Lulek 2015); however, more work is necessary in the further development of future government test methods and the modification of current protocols. 


\subsection{Conclusion}

\subsection{Summary of Findings}

The potential sub-lethal, chronic, and lethal toxicity of biosolids when they are applied under environmentally-relevant conditions was measured using two terrestrial phyla, Folsomia candida (springtails) and Lumbricus terrestris (earthworms or 'nightcrawlers'). Biosolids showed no noticeable significant effect when applied, at environmentally-relevant concentrations, on terrestrial organisms; however, results for $L$. terrestris avoidance at the worst-case (22-tonnes ha- ${ }^{-1}$ ) application regime needs to be further replicated. While continuous evaluation of the status of toxicity of biosolids is necessary, it is the position of many governing agencies, such as the Australian-New Zealand Biosolids Partnership (AZNBP) that "until further information indicates otherwise... the benefits outweigh risks of biosolids landapplication”. The AZNBP summarizes the comprehensive benefits of biosolids (Batstone et al. 2020):

Overall, consideration of the environmental, economic and social benefits of biosolids land application provides multiple benefits through recycling of valuable nutrients to depleted soils, reduced reliance on petrochemical and mined sources of plant nutrients, and cost-effective management of municipal wastewater, with no known major detrimental effects to soil, plants, the food chain, human health or soil and water organisms in the past 20 years of modern biosolids reuse standards and monitoring in Australia and New Zealand.

The lack of toxicity effects on terrestrial organisms in the current study indicates that the engineered strategy of land-applying biosolids is a sustainable practice.

\subsection{Consideration for Further Research}

Building upon this research, we suggest multiple considerations for future biosolids research. These include i) the environmental relevance of test organisms, ii) current-recommended bioassays and their endpoints, and iii) using whole-organism indicators instead of solely depending on chemical analysis.

\subsubsection{Environmental Relevance in Organism Selection}

While several studies report upon the toxic effects of biosolids on Eisenia sp., these observations must be prefaced with the information that Eisenia sp. are rarely found in an environment where biosolids are land-applied. While current government protocols support the use of both Eisenia sp. and Lumbricus terrestris, environmental relevance must be of paramount importance in ecotoxicological testing and thus, $L$. terrestris is strongly recommended as they occupy fields frequented in wheat-corn-soybean rotations (EC 2007a; Kinney et al. 2008). The lack of existing studies using Lumbricus terrestris limit the comparability of results in the current study to other biosolids toxicity testing. Moreover, the use of Eisenia sp. due to their low cost, ease in lab rearing, and their past use in studies should not be sufficient reasons to validate them as a test organism in biosolids toxicity testing. In 1994, the USEPA strongly suggested that the selection of a test organism(s) should be "a species that is representative of resident 
organisms, sensitive to site contaminants, relevant to overall assessment endpoints, and consistent with DQOs [or data quality objectives]" (USEPA 1994). Rigorous science historically (Giesy and Hoke 1989), and currently (Johnson and Sumpter 2016), would uphold the use of environmentally-relevant organisms to the application of testing, not solely depend on parameters such as ease-of-use.

\subsubsection{Constraints of Current Bioassays}

Current bioassays in the literature, and the endpoints measured, do not capture the holistic series of impacts of biosolids on terrestrial animals. Sub-lethal effects, notably, are disregarded in toxicity arrays in favour of lethal and chronic testing. Despite the USEPA acknowledging that "sublethal effects" measured in laboratories "are ecologically significant effects when occurring in the environment", a lack of sublethal arrays is exchanged for lethality bioassays (USEPA 1994). In this study, avoidance bioassays for springtails were developed to test the sublethal and chronic effects of biosolids, to supplement existing government protocols for lethality testing. Bioassays explicitly need to better represent environmental conditions as their size and construction limit the observation of sub-lethal effects. For example, chronic bioassays for Lumbricus terrestris currently are conducted in small vessels in the laboratory which do not allow the kind of burrowing behaviour and complete elongation of the annelid that occurs in the field. The use of Evans' boxes (Evans 1947), with the attached reproduction chambers, while more resource intensive, better represents environmental conditions in which the worm operates (Lulek 2015).

Similarly, 'shoebox' rectangular bins were used for sub-lethal testing of Lumbricus terrestris instead of Kaushik chambers. Only a few other studies documented in the literature have used rectangular vessels for toxicity testing. Wentsel and Guelta (1988) used rectangular containers to test the effects of brass powder-spiked soils. The rationale against using rectangular vessels has been suggested to avoid edgeeffects, as it has been postulated that earthworms preferably seek corners to avoid toxicants (Yeardley et al. 1996). However, Kaushik chambers have corners, so their use would make it impossible to avoid edgeeffects. Additionally, these chambers were originally constructed for aquatic sediment toxicity testing (EC 2004; EC 2007a) and their incorporation into terrestrial ecotoxicological studies do not allow earthworms to exhibit full extent of movement. Moreover, rectangular bins better accommodate soil horizons and therefore are more representative of environmental conditions.

\subsubsection{Whole-Organism Indicators of Toxicity}

Results of this study support the validity of whole-organism testing, as opposed to chemical analysis and/or "omics" experiments, for determining potential toxicity. Current studies routinely evaluate toxicity through single chemicals or groups of compounds in spiking tests and or chemical analysis. Thus, many parent compounds and their attendant degradative by-products are ignored while potentially being problematic. Assessing toxicity of a compound on an organism with only a single endpoint is an erroneous task which yields environmentally-irrelevant results when compared to holistic, whole-organism tests.

As it was for the determination of phosphorus as the limiting nutrient to algal growth (Schindler et al. 2016), it is critical that future experiments incorporate field (in situ) sites for future testing, as opposed to 
simply extrapolating results from lab bioassays. While results in the current study indicate a lack of significant effects when biosolids are land-applied to specific organisms, there remains a critical need for the following: testing that incorporates environmentally-relevant organisms in field conditions that measures sublethal, chronic, and lethal toxicity endpoints.

\subsection{Declarations}

\subsection{Data Availability}

Data is available on request to the corresponding author.

\subsection{Animal Research (Ethics)}

Not Applicable

\subsection{Consent to Participate (Ethics)}

Not Applicable

\subsection{Consent to Publish (Ethics)}

Not Applicable

\subsection{Clinical Trials Registrations}

Not Applicable

\subsection{Author Contribution}

This study conceptualization and methodology was established by KJP and LHM, the formal analysis and investigation was conducted by KJP, LHM, and BMS. The preparation of the original draft, in addition to review and edits were conducted by BMS, KJP, and LHM. Funding and resources for this study was acquired by LHM.

\subsection{Conflicts of Interest}

Not Applicable

\subsection{Funding}

Significant funding for this research was provided by NSERC DG and the Ontario Ministry of the Environment (OMOE). Partial financial support was provided by Ryerson University Faculty of Science.

\section{Acknowledgements}


The authors would like to acknowledge Michael Payne of the Ontario Ministry of Agriculture, Food, and Rural Affairs (OMAFRA) and Shelly Bonte-Gelok of the Ministry of Environment (MOE) for their extensive insight into the land-application of biosolids, including production processes ; KJP would like to acknowledge A. Laursen and V. Bostan of Ryerson University (RU) for their feedback on the results observed in this research.

\subsection{Works Cited}

1. Aldaya MM, Lors C, Ponge J, Salmon S (2006) Avoidance Bio-assays may Help to Test the Ecological Significance of Soil Pollution. Environ Pollut 40:173-180.

https://doi.org/10.1016/j.envpol.2005.06.011

2. Artuso N, Kennedy TF, Connery J, Grant J, Schmidt O (2011) Effects of biosolids at varying rates on earthworms (Eisenia fetida) and springtails (Folsomia candida). Applied and Environmental Soil Science 2011:519485. https://doi.org/10.1155/2011/519485

3. Ayers R (2021) Earthworms, more than Fish Bait. Colorado State University Cooperative Extension Master Gardener. http://www.extension.colostate.edu/4DMG/Soil/worms.htm. Accessed on 4 February 2022

4. Banks MK, Schwab AP, Alleman JE, Cofield N, Shalabi J, Switzenbaum M, Williams P (2006) Biosolids-Amended Soils: Part I. Effect of Biosolids Application on Soil Quality and Ecotoxicity. Water Environ Res 78(11): 2217-2230. https://doi.org/10.2175/106143005X86637

5. Batstone D, Dale G, Randall HW, Tao E, Water M (2020) ANZBP Preliminary Report on Microplas Fründ tics Risk for the Australian and New Zealand Biosolids Industry July 2020. Australia-New Zealand Biosolids Partnership (AZNBP). https://www.biosolids.com.au/wp-content/uploads/ANZBPMicroplastics-Prelim-Report-2020-Web.pdf. Accessed 4 February 2022

6. Blackmon IV JH (2009) The use of fire in the control of invasive, epigeic earthworm species in the Southeastern United States. Dissertation, University of Georgia

7. Bouldin JL, Klasky JW, Green VS (2016) Earthworm Preference Bioassays to Evaluate Land Management Practices. B Environ Contam Tox 96(6): 767-772. https://doi.org/10.1007/s00128-0161744-4

8. Burton Jr GA (1991) Assessing the Toxicity of Freshwater Sediments. Environ Toxicol Chem 10(12):1585-1627. https://doi.org/10.1002/etc.5620101204

9. Butt KR, Nuutinen V (1998) Reproduction of the Earthworm Lumbricus terrestris Linné After The First Mating. Can J Zool 76:104-109

10. Cairns Jr K, Mount DI (1990) Aquatic Toxicology. Environmental Science and Technology 24:154161. https://doi.org/10.1021/es00072a001

11. California Environmental Protection Agency (CalEPA) (2009) Soil Toxicity and Bioassessment Test Methods for Ecological Risk Assessment - Toxicity Test Methods for Soil Microorganisms, Terrestrial Plants, Terrestrial Invertebrates and Terrestrial Vertebrates. CaIEPA. 
https://oehha.ca.gov/media/downloads/ecotoxicology/document/soiltox120208.pdf. Accessed 8 September 2021

12. Campiche S, L'Ambert G, Becker-van Slooten K, Tarradellas J (2007) Multigenerational Effect of Inset Growth Regulators on the Springtail Folsomia candida. Ecotox Environ Safe 67:180-189. https://doi.org/10.1016/j.ecoenv.2006.11.009

13. Canadian Council of Ministers of the Environment (CCME) (2013) Emerging Substances of Concern in Biosolids: Concentrations and Effects of Treatment Processes. CCME.

https://publications.gc.ca/collections/collection_2013/ccme/En108-4-58-2010-eng.pdf. Accessed 4 February 2022

14. Cardoso DN, Oliveira M, Loureiro S, Soares AM (2021) Susceptibility of Folsomia candida to agrochemicals after multigenerational exposure to human pharmaceuticals. Environ Toxicol Chem 0:1-9. https://doi.org/10.1002/etc.5013

15. City of Guelph (2009) Guelph Wastewater Treatment Master Plan. City of Guelph. https://guelph.ca/wp-content/uploads/Wastewater-Treatment-Master-Plan.pdf. Accessed 4 February 2022

16. City of Toronto (2009) Biosolids and Residuals Master Plan Update: Prepared by AECOM Canada Ltd for the City of Toronto. Project No. 2523.01 (374333601). City of Toronto. https://www.toronto.ca/legdocs/mmis/2009/pw/bgrd/backgroundfile-24358.pdf. Accessed 1 October 2009.

17. Clark B, Porter N, Blackbeard J, Marriot P, Stevenson G, Symons R (2010) Investigating the Distribution of Polybrominated Diphenyl Ethers through an Australian Wastewater Treatment Plant. Sci Total Environ 408:1604-1611. https://doi.org/10.1016/j.scitotenv.2009.11.059

18. Collier HO (1937) The Immobilization of Locomotory Movements in the Earthworm Lumbricus terrestris. J Exp Biol 15(3): 339-357. https://doi.org/10.1242/jeb.15.3.339

19. Colorado State University (2011) Colorado Master Gardener Program - Garden Notes \#218 Earthworms. Colorado State University Extension. http://www.cmg.colostate.edu/gardennotes/218.pdf. Accessed 22 January 2018.

20. Coors A, Edwards M, Lapen DR, Lorenz P, Römbke J, Schmelz RM, Topp E, Waszak K, Wilkes G (2016) Biosolids applied to agricultural land: Influence on structural and functional endpoints of soil fauna on a short-and long-term scale. Sci Total Environ 562:312-326. https://doi.org/10.1016/j.scitotenv.2016.03.226

21. Crouau $Y$, Cazes $L$ (2003) What causes variability in the Folsomia candida reproduction test?. Appl Soil Ecol 22(2):175-180. https://doi.org/10.1016/S0929-1393(02)00128-2

22. Crouau Y, Chenon P, Gisclard C (1999) The Use of Folsomia candida (Collembola, Isotomidae) for the Bioassay of Xenobiotic Substances and Soil Pollutants. Appl Soil Ecol 12:103-111. https://doi.org/10.1016/S0929-1393(99)00002-5

23. Crouau Y, Gisclard C, Perotti P (2002) The Use of Folsomia candida (Collembola, Isotomidae) in Bioassays of Waste. Appl Soil Ecol 19:65-70. https://doi.org/10.1016/S0929-1393(01)00175-5 
24. Crouau Y, Moia C (2006) The Relative Sensitivity of Growth and Reproduction in the Springtail, Folsomia Candida, Exposed to Xenobiotics in the Laboratory: an Indicator of Soil Toxicity. Ecotox Environ Safe 64:115-121. https://doi.org/10.1016/j.ecoenv.2005.06.002

25. DeBruyn J, Hilborn D (2007) Anaerobic Digestion Basics Fact sheet. Ontario Ministry of Agriculture, Food and Rural Affairs (OMAFRA). http://www.omafra.gov.on.ca/english/engineer/facts/07057.htm. Accessed 4 February 2022

26. Environment Canada (2004) Guidance Document for Testing the Pathogenicity and Toxicity of New Microbial Substances to Aquatic and Terrestrial Organisms (EPS 1/RM/44 March 2004). Environment Canada. https://publications.gc.ca/site/eng/9.560493/publication.html. Accessed 14 September 2021

27. Environment Canada (2007a) Biological Test Method: Tests for Toxicity of Contaminated Soil to Earthworms (Eisenia andrei, Eisenia fetida, or Lumbricus terrestris) (EPS 1/RM/43. i-156 p). Environment Canada. https://publications.gc.ca/site/eng/9.575869/publication.html. Accessed 14 September 2021

28. Environment Canada (2007b) Draft Copy - Biological Test Method: Test or Measuring Survival and reproduction of Springtails Exposed to Contaminants in Soil (EPS 1/RM/47).

29. Environment Canada. https://publications.gc.ca/collections/collection_2015/ec/En49-7-1-47-1eng.pdf. Accessed 14 September 2021

30. Environment Canada (2007c) SOP No 15.29/1.0/S - Springtail Culturing and Maintenance, Environmental Science and Technology Centre. Environment Canada. https://www.canada.ca/en/environment-climate-change/services/wildlife-research-landscapescience/biological-test-method-publications/survival-springtails/chapter-2.html. Accessed 14 September 2021

31. Environment Canada (2007d) SOP No. 15.30/1.0/S - Springtail Age-Synchronization, Environmental Science and Technology Centre. Environment Canada. https://www.canada.ca/en/environmentclimate-change/services/wildlife-research-landscape-science/biological-test-methodpublications/survival-springtails/chapter-2.html. Accessed 14 September 2021

32. Environment Canada (2007e) SOP No. 15.31/1.0/S - Springtail Reference Toxicant Test, Environmental Science and Technology Centre. Environment Canada. https://publications.gc.ca/collections/collection_2015/ec/En49-7-1-47-1-eng.pdf. Accessed 14 September 2021

33. Environment Canada (2008) SOP No 15.32/1.1/S - Toxicity of Contaminated Soil to Springtails: Reproduction. Environment Canada. https://publications.gc.ca/collections/collection_2012/ec/En497-1-47-eng.pdf. Accessed 14 September 2021

34. Environment Canada (2014) Biological test method for measuring survival of springtails exposed to contaminants in soil: chapter 1, EPS 1/RM/47 Second Edition. Environment Canada. https://www.canada.ca/en/environment-climate-change/services/wildlife-research-landscape- 
science/biological-test-method-publications/survival-springtails/chapter-1.html. Accessed 14 September 2021

35. Evans AC (1947) LVII-A method of studying the burrowing activities of earthworms. Ann Mag Nat Hist 14(117):643-650.

36. Fountain MT, Hopkin SP (2005) Folsomia candida (Collembola): A "Standard" Soil Arthropod. Annu Rev Entomol 50:201-22. https://doi.org/10.1146/annurev.ento.50.071803.130331

37. Fründ C, Butt K, Capowiez Y, Eisenhauer N, Emmerling C, Ernst G, Potthoff M, Schadler M, Schrader S (2010) Using Earthworms as Model Organisms in the Laboratory: Recommendations for Experimental Implementations. Pedobiologia 53:119-125.

https://doi.org/10.1016/j.pedobi.2009.07.002

38. Giesy J, Hoke R (1989) Freshwater Sediment toxicity Bioassessment: Rationale for Species Selection and Test Design. J Great Lakes Res 15(4): 539-569. https://doi.org/10.1016/S0380-1330(89)715100

39. Gomes AR, Justino C, Duarte AC, Freitas AC, Pereira R, Rocha-Santos T (2017) Review of the ecotoxicological effects of emerging contaminants to soil biota. J Environ Sci Heal A 52(10):9921007. https://doi.org/10.1080/10934529.2017.1328946

40. Groth VA, Carvalho-Pereira T, da Silva EM, Niemeyer JC (2016) Ecotoxicological assessment of biosolids by microcosms. Chemosphere 161:342-348. https://doi.org/10.1016/j.chemosphere.2016.07.029

41. Grue CE, Gardner SC, Gibert PL (2002) On the significance of pollutant-induced alterations in the behaviour of fish and wildlife. In: Dell'Omo G (ed) Behavioural Ecotoxicology. John Wiley \& Sons, UK, pp 1-89.

42. Hellou J (2011) Behavioural ecotoxicology, an "early warning" signal to assess environmental quality. Environ Sci Pollut R 18(1):1-11. https://doi.org/10.1007/s11356-010-0367-2

43. Hopkin SP (1997) The Biology of the Collembola (Springtails): The Most Abundant Insects in the World. Natural History Museum. http://www.fathom.com/feature/122603/. Accessed 18 September 2021

44. Houseman RM (2007) Springtails, Division of Plant Sciences. MU Guide - Insects and DiseasesSpringtails. University of Missouri-Columbia. http://extension.missouri.edu/explorepdf/agguides/pests/g07363.pdf. Accessed 3 December 2018

45. Huguier P, Manier N, Bauda P, Chabot L, Pandard P (2015) Ecotoxicological assessment of organic wastes spread on land: Towards a proposal of a suitable test battery. Ecotox Environ Safe 113:103111. https://doi.org/10.1016/j.ecoenv.2014.11.017

46. Imrie D (2013). Controversial Cambridge Biosolids Plant on-Hold. CTV News Kitchener. https://kitchener.ctvnews.ca/controversial-cambridge-biosolids-plant-on-hold-1.1447142/comments7.433274. Accessed 18 September 2021

47. International Standards Organization (ISO) (2008) 17512-1: Soil quality-avoidance test for determining the quality of soils and effects of chemicals on behaviour-Part 1 : test with earthworms 
(Eisenia fetida and Eisenia andrei). International Organization for Standardization.

https://www.iso.org/standard/38402.html. Accessed 4 February 2022

48. Jesmer AH, Velicogna JR, Schwertfeger DM, Scroggins RP, Princz JI (2017) The toxicity of silver to soil organisms exposed to silver nanoparticles and silver nitrate in biosolids-amended field soil. Environ Toxicol Chem 36(10):2756-2765. https://doi.org/10.1002/etc.3834

49. Johnson AC, Sumpter JP (2016) Are we going about chemical risk assessment for the aquatic environment the wrong way?. Environ Toxicol Chem 35(7):1609-1616.

https://doi.org/10.1002/etc.3441

50. Key J (1997) Research Design in Occupational Education Module S7 - Chi-Square. Oklahoma State University. http://www.okstate.edu/ag/agedcm4h/academic/aged5980a/5980/newpage28.htm. Accessed 6 April 2018.

51. Kinney CA, Campbell BR, Burkhardt MR, Furlong ET, Hay AG, Kolpin DW, Thompson R, Werner SL, Zaugg SD (2012). Earthworm bioassays and seedling emergence for monitoring toxicity, aging and bioaccumulation of anthropogenic waste indicator compounds in biosolids-amended soil. Sci Total Environ 433:507-515. https://doi.org/10.1016/j.scitotenv.2012.06.097

52. Kinney CA, Furlong ET, Benotti M, Burkhardt MR, Bossio J, Kolpin DW, Werner S, Zaugg SD (2008) Bioaccumulation of Pharmaceuticals and Other Anthropogenic Waste Indicators in Earthworms from Agricultural Soil Amended With Biosolids or Swine Manure. Environmental Science and Technology 42(6):1863-1870. https://doi.org/10.1021/es702304c

53. Kinney CA, Furlong ET, Cahill J, Burkhardt MR, Jorgensen G, Werner SL, Zaugg SD (2006) Survey of Organic Wastewater Contaminants in Biosolids Destined for Land Application. Environmental Science and Technology 40:7207-7215. https://doi.org/10.1021/es0603406

54. Krogh PH (2008) Toxicity Testing With the Collembolans Folsomia fimetaria and Folsomia candida and the Results of a Ringtest. Danish EPA. https://www.oecd.org/chemicalsafety/testing/41389036.pdf. Accessed 30 September 2008

55. Lapen DR, Topp E, Edwards M, Gottschall N (2018) Land application of municipal biosolids: managing the fate and transport of contaminants of emerging concern. Detritus 1(1):122. https:/doi.org/10.26403/detritus/2018.18

56. LeBlanc TR (2007) Regulating Biosolids and Biosolids Management in Canada. Council of European Professional Informatics Societies. http://www.cepis.opsoms.org/bvsaar/cdlodos/pdf/regulatingbiosolids69.pdf. Accessed 9 December 2018

57. Li S, Zhu L, Christie P, Li J, Luo Y, Ke X, Wu L (2020) Influence of long-term biosolid applications on communities of soil fauna and their metal accumulation: A field study. Environ Pollut 260:114017. https://doi.org/10.1016/j.envpol.2020.114017

58. Little EE (1990) Behavioral toxicology: stimulating challenges for a growing discipline. Environ TOXICOL Chem 9:1-2. https://doi.org/10.1002/etc.5620090101

59. Little EE, Finger SE (1990) Swimming behavior as an indicator of sublethal toxicity in fish. Environ Toxicol Chem 9(1):13-19. https://doi.org/10.1002/etc.5620090103 
60. Lowe C (2008). Earthworms. University of Central Lancashire.

http://www.uclan.ac.uk/scitech/earthworm_research/faqs.php\#3. Accessed 17 December 2014.

61. Lucas $P$ (2020) Comment: Keep sewage sludge off farms, fields and forests. Times Colonist. https://www.timescolonist.com/opinion/op-ed/comment-keep-sewage-sludge-off-farms-fields-andforests-1.24081839. Accessed 9 December 2020

62. Lulek AM (2015) Assessing the Burrowing Behaviour of Eisenia sp. And Lumbricus terrestris in Evan's Boxes for Future Testing of Land-Application of Biosolids. Dissertation, Ryerson University

63. McCarthy LH, Loyo J (2015) Risks associated with Municipal Biosolids Application to Agricultural Lands in Canada - Literature Review. Canadian Water Network. https://cwn-rce.ca/wpcontent/uploads/2015/08/McCarthy-Risks-Biosolids-2015.pdf Accessed 4 February 2022

64. McDonald JH (2009) Handbook of Biological Statistics (2nd ed.). Sparky House Publishing, Maryland, pp 191-197.

65. Melo TM, Bottlinger M, de Aguiar Filho AM, Leandro WM, Ok YS, Rinklebe J, Schulz E (2017) Effect of biosolid hydrochar on toxicity to earthworms and brine shrimp. Environ Geochem Hlth 39(6):13511364. https:/doi.org/10.1007/s10653-017-9995-5

66. Natal-da-Luz T, Römbke J, Sousa JP (2008) Avoidance tests in site-specific risk assessmentinfluence of soil properties on the avoidance response of collembola and earthworms. Environ Toxicol Chem 27(5):1112-1117. https:/doi.org/10.1897/07-386

67. North East Biosolids \& Residuals Association (NEBRA) (December 2008) Information Update: Official Usage of the Term "Biosolids". NEBRA. http://www.nebiosolids.org/uploads/pdf/Biosolids-theWordNEBRA08.pdf. Accessed 21 December 2008

68. O’Connor GA, Elliott HA, Basta NT, Bastina RK, Pierzynski GM, Sims RC, Smith JE Jr (2005) Sustainable Land Application: An Overview. J Environ Qual 35(1):7-17. https://doi.org/10.2134/jeq2005.0007

69. OECD (Organization for Economic Co-operation and Development). (1984). Guidelines for Testing of Chemicals \# 207 - Earthworm, Acute Toxicity Tests. https://doi.org/10.1787/20745761

70. OECD (Organization for Economic Co-operation and Development) . (2004). Guidelines for the Testing of Chemicals - Earthworm Reproduction Test (Eisenia fetida/Eisenia andrei). Report No. 222. OECD. https://www.oecd.org/env/ehs/testing/Draft-Updated-Test-Guildeline 222-Earthworm reproduction-Test.pdf. Accessed 4 February 2022

71. OECD (Organization for Economic Cooperation and Development). (2005). OECD Guideline for the Testing of Chemicals: Proposal for a New Guideline C Collembola Reproduction Test (Folsomia fimetaria and Folsomia candida). OECD. https://www.oecd.org/chemicalsafety/testing/41388670.pdf. Accessed 19 September 2019

72. Oleszczuk P, Czech B, Bogusz A, Godlewska P, Kończak M, Siatecka A, Wiesner M (2019) Impact of $\mathrm{ZnO}$ and $\mathrm{ZnS}$ nanoparticles in sewage sludge-amended soil on bacteria, plant and invertebrates. Chemosphere 237:124359. https://doi.org/10.1016/j.chemosphere.2019.124359 
73. Peakall DB (1996) Disrupted patterns of behavior in natural populations as an index of ecotoxicity. Environ Health Persp 104(Suppl.):331-5. https://doi.org/10.1289/ehp.96104s2331

74. Pepper I, Brooks J, Gerba C (2006). Pathogens in Biosolids. Adv Agron 90:1-41. https://doi.org/10.1016/S0065-2113(06)90001-7

75. Puddephatt K, McCarthy LH, Serre BM (2022) Is Land-Applying Biosolids to Agricultural Areas "Sustainable"? Part Two: Assessing the Potential Chronic, Lethal, and Multigenerational Ecotoxicity of Biosolids on Zea Mays, Glycine Max, Phaseolus Vulgaris and Brassica Rapa. Ecotoxicology. (Submitted Ecotoxicology)

76. Raby M (2013) Toxicity Assessment of The Antimicrobial Triclocarban Using Sub-Lethal Behaviour and Reproduction Endpoints. Dissertation, Ryerson University

77. Reilly M (2001) The Case Against Land Application of Sewage Sludge Pathogens. Can J Infect Dis Med 12(4): 205-207. https://doi.org/10.1155/2001/183583

78. Residua (2003) Anaerobic Digestion Information Sheet. North Yorkshire UK. Company Formed to Provide Information of Sustainable Management of Municipal Solids Waste. http://www.residua.com/Residua/. Accessed 8 July 2013

79. Rogers M, Smith SR (2007) Ecological Impact of Application of Wastewater Biosolids to Agricultural Soil. Water Environ J 21:34-40. https://doi.org/10.1111/j.1747-6593.2006.00043

80. Samoiloff MR (1989) Toxicity testing of sediments: Problems, trends, and solutions. Advances in Environmental Science and Technology. In: JO Nriagu, Lakshminarayana JSS (eds.) Aquatic Toxicology and Water Quality Management. Wiley and Sons, New York, pp. 143-152

81. Sanchez-Hernandez JC (2021) Vermiremediation of Pharmaceutical-Contaminated Soils and Organic Amendments. In: Solsona, SP, Montemurro N, Chiron S, Barcelo D (eds.), Handbook of Environmental Chemistry. Springer Science+Business Media, Germany. https://doi.org/10.1007/9783-030-61290-0

82. Schindler DW, Carpenter SR, Chapra SC, Hecky RE, Orihel DM (2016) Reducing phosphorus to curb lake eutrophication is a success. Environ Sci Technol 50(17):8923-8929. https://doi.org/10.1021/acs.est.6b02204

83. Scott-Fordsmand J, Krogh P (2005) Background report on pre-validation of an OECD Springtail Test Guideline (Environmental Project Nr. 9862005 Miljoprojekt). Danish Ministry of the Environment. https://www2.mst.dk/Udgiv/publications/2005/87-7614-535-2/pdf/87-7614-536-0.pdf. Accessed 13 July 2013

84. Sewage Treatment (2010) Foundation for Water Research - Sewage Treatment Guidelines. Foundation for Water Research. http://www.euwfd.com/html/sewage_treatment.html. Accessed 13 July 2013

85. Staples C, Friederich URS, Caspers, N, Hall T, Hentges, S, Klečka G, Mihaich E, Ortego L (2010) Estimating potential risks to terrestrial invertebrates and plants exposed to bisphenol $\mathrm{A}$ in soil amended with activated sludge biosolids. Environ Toxicol Chem 29(2):467-475. https://doi.org/10.1002/etc.49 
86. Stephenson G, Kaushik A, Kaushik N, Soloman K, Steele T, Scroggins RP (1998) Use of an AvoidanceResponse Test to Assess the Toxicity of Contaminated Soils to Earthworms. In: Sheppard S, Bombridge J, Holmstrup M, Posthuma L (eds.) Advances in Earthworm Ecotoxicology: Proceedings from the Second International Workshop on Earthworm Ecotoxicology, 2-5 April 1997. Setac Gen P.

87. Snyder EH, O'Connor GA, McAvoy D (2011) Toxicity and Bioaccumulation of Biosolids-Borne Triclocarban (TCC) in Terrestrial Organisms. Chemosphere 82(3):460-467. https://doi.org/10.1016/j.chemosphere.2010.09.054

88. Synagro (2002) About Biosolids: Frequently Asked Questions. Synagro. http://www.biosolids.com/faq.html\#25fd. Accessed 01 October 2009

89. Taylor LN, Scroggins RP (2013) Biological Test Methods In Ecotoxicology. In: Ferard JF, Blaise C. (eds.) Encyclopedia of Aquatic Ecotoxicology. Springer Science+Business Media; Dordrecht. https://doi.org/10.1007/978-94-007-5704-2_19

90. Toronto Water (2004) Where Does the Water From Your Toiled Go? City of Toronto. http://www.toronto.ca/water/wastewater_treatment/pdf/wastewater_poster.pdf. Accessed 27 November 2010.

91. Toronto Water (2019) City of Toronto Wastewater Treatment Plant Annual Reports - Ashbridges Bay Wastewater Treatment Plant 2019 Annual Report. City of Toronto. https://www.toronto.ca/wpcontent/uploads/2019/05/8fOf-2018-TAB-Annual-Report-FINAL-ecopy.pdf. Accessed 28 June 2021.

92. United States Environmental Protection Agency (USEPA) Office of Solid Waste and Emergency Response (1994) ECO Update: Using Toxicity Tests in Ecological Risk Assessment (Intermittent Bulletin 2:1). https://www.epa.gov/sites/default/files/2015-09/documents/v2no1.pdf. Accessed 28 June 2021

93. United States Environmental Protection Agency (USEPA) (2000) Biosolids Technology Fact SheetLand-application of Biosolids (Report No. EPA 832-F-00-064). USEPA. https://www.epa.gov/sites/default/files/2018-11/documents/land-application-biosolidsfactsheet.pdf. Accessed 4 February 2022

94. United States Environmental Protection Agency (USEPA) (2021) Toxic Substances Control Act Inventory. USEPA. https://www.epa.gov/tsca-inventory/about-tsca-chemical-substance-inventory. Accessed 28 June 2021

95. University of Waterloo Cyberspace Chemistry (CAcT) (n.d.) General Wastewater Treatment in Waterloo, ON. University of Waterloo. http://www.science.uwaterloo.ca/ cchieh/cact/applychem/watertreatment.html. Accessed 28 June 2021

96. Velicogna JR, Ritchie E, Princz J, Lessard ME, Scroggins RP (2012) Ecotoxicity of siloxane D5 in soil. Chemosphere 87(1):77-83. https://doi.org/10.1016/j.chemosphere.2011.11.064

97. Velicogna, JR (2019) An Investigation into the Effects of Nano Copper Oxide to the Soil Invertebrates Eisenia Andrei and Folsomia Candida. Dissertation, Carleton University 
98. Vyhnak, C (2008) Toronto Star Sludge Series: Soiled Land. Toronto Star. https://www.thestar.com/opinion/2008/07/19/sludge_series_had_the_dirt_on_biosolids.html. Accessed 28 June 2021

99. Wentsel RS, Guelta MA (1988) Avoidance of Brass Powder-Contaminated Soil by the Earthworm, Lumbricus Terrestris. Environ Tox Chem 7(3):241-243. https://doi.org /10.1897/15528618(1988)7[241:AOBPSB]2.0.CO;2

100. Wiles JA, Krogh PH (1998) Testing with the Collembolans I. viridis, F. candida and F. fimetaria. In: Lokke H, Van Gestal CAM, (eds.) In Handbook of Soil Invertebrate Toxicity Test. OECD. https://www.oecd.org/chemicalsafety/testing/41389036.pdf. Accessed February 42022.

101. Wilke BM, Riepert R, Koch C, Kühne T (2008) Ecotoxicological Characterization of Hazardous Wastes. Ecotox Environ Safe: 70:283-293. https://doi.org/10.1016/j.ecoenv.2007.10.003

102. Wu C, Sprongberg A, Witter J (2008) Determination of the Persistence of Pharmaceuticals in Biosolids Using Liquid-Chromatography Tandem Mass Spectrometry. Chemosphere 73(4):511-518. https://doi.org/10.1016/j.chemosphere.2008.06.026

103. Xue J, Kimberley MO, Champeau O, Gielen G, Horswell J, Ross C, Tremblay LA, Wang H. (2015) Ecological impacts of long-term application of biosolids to a radiata pine plantation. Sci Total Environ 530:233-240. https://doi.org/10.1016/j.scitotenv.2015.05.096

104. Yeardley Jr RB, Gast LC, Lazorchak JM (1996) The Potential of an Earthworm Avoidance Test for Evaluation of Hazardous Waste Sites. Environ Toxicol Chem 15(9):1532-1537. https://doi.org/10.1002/etc.5620150915

105. Zar JH (1984) Biostatistics: Analysis, Second Edition. New Jersey, USA. Prentice Hall Inc.

\section{Figures}




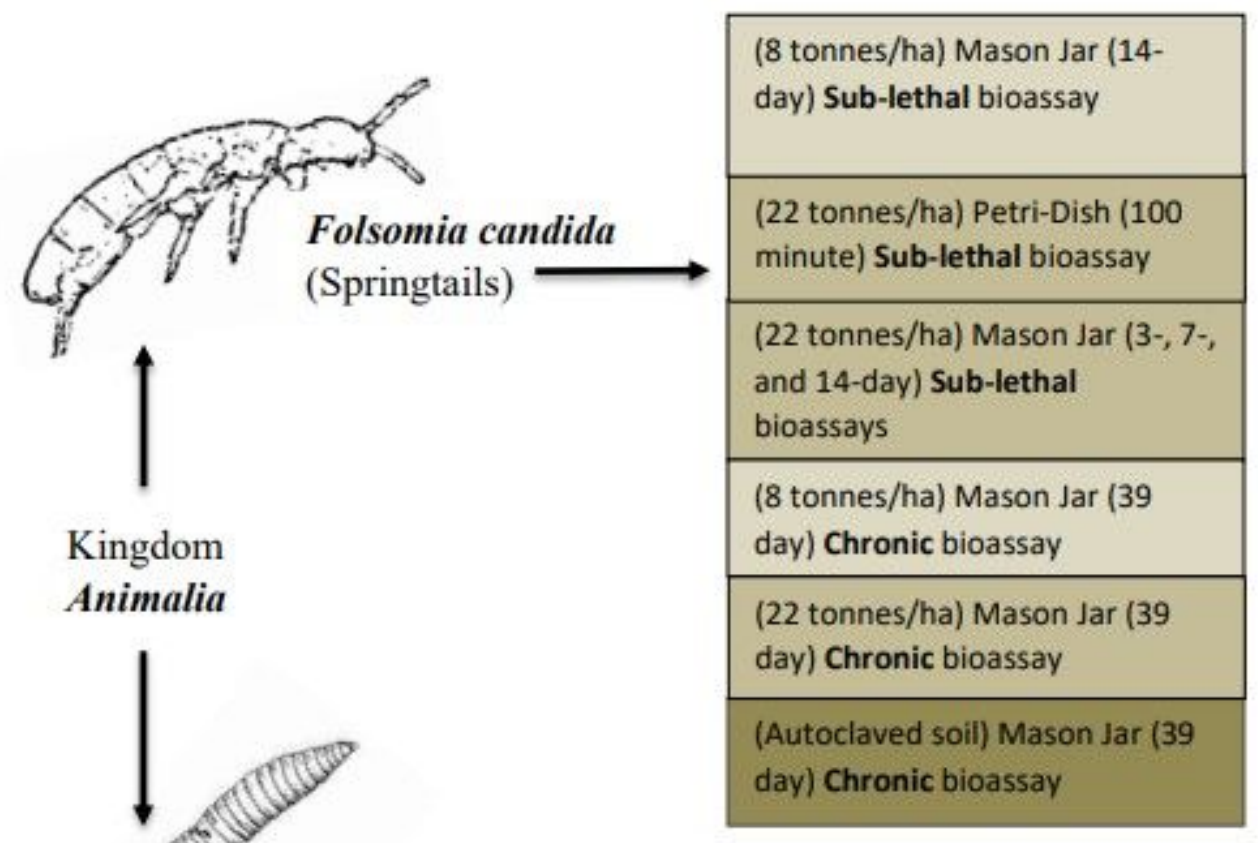

\section{Lumbricus terrestris (Earthworms) \\ (22 tonnes/ha) Shoebox (3 Day) Sub-lethal bioassay \\ (22 tonnes/ha) Evans Box (90 Day) Sub-lethal/Chronic bioassay}

\section{Figure 1}

Bioassays conducted on Folsomia candida and Lumbricus terrestris. Guelph WWTP Biosolids (dark grey) are differentiated from Kitchener WWTP biosolids (light grey) in the volumes of 8 and 22 tonnes/ha, respectively. Lethality was measured in all bioassays. 


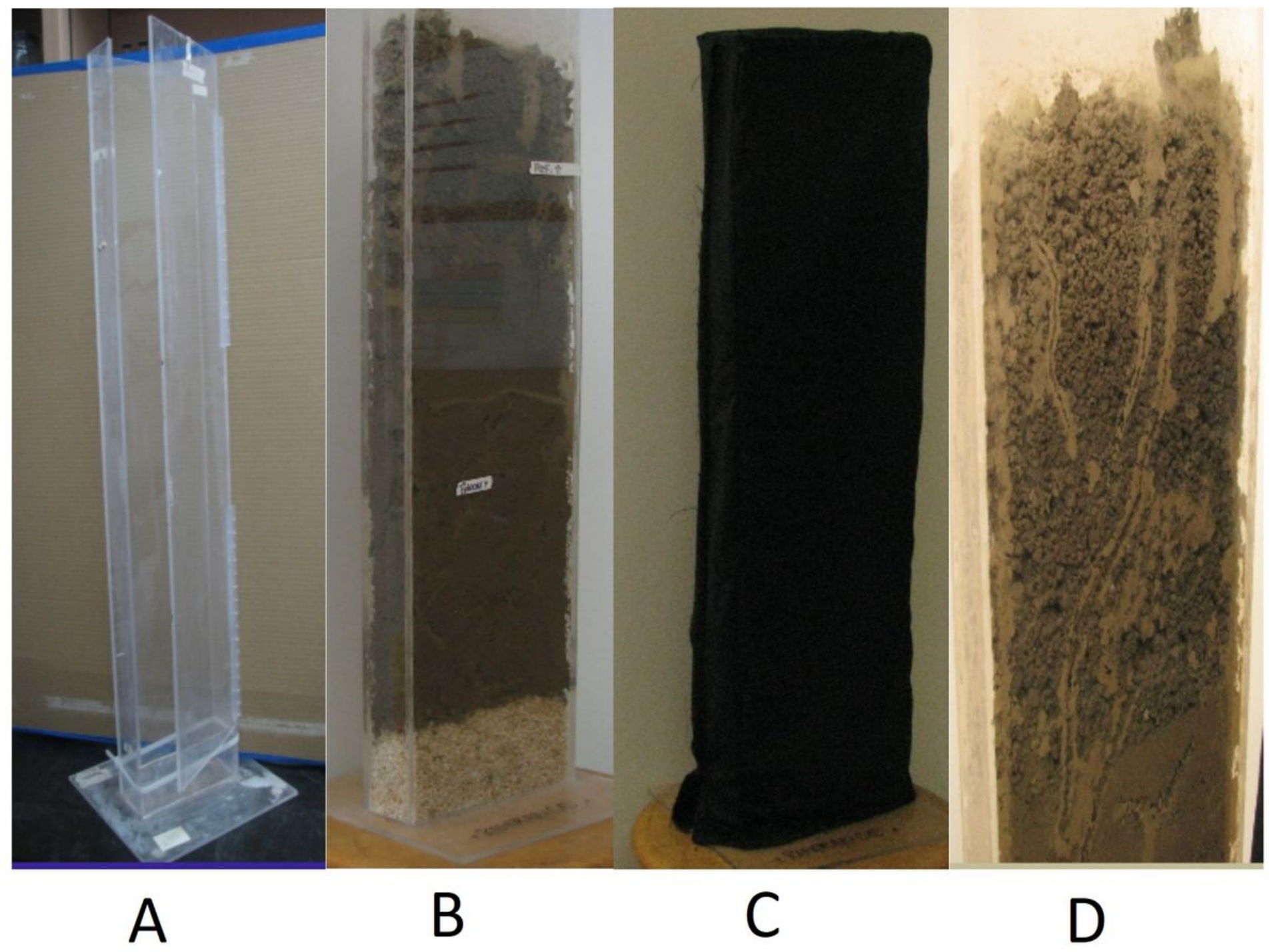

Figure 2

Quadriptych of modified Evans' boxes with an operable door (A), filled with the soil horizons (B), secured with fabric to simulate below ground conditions (C), and visualization of the burrowing behaviours $(D)$. 